ENTREPRENEURSHIP AND SUSTAINABILITY ISSUES

ISSN 2345-0282 (online) http://jssidoi.org/jesi/ 2021 Volume 9 Number 1 (September)

http://doi.org/10.9770/jesi.2021.9.1(32)
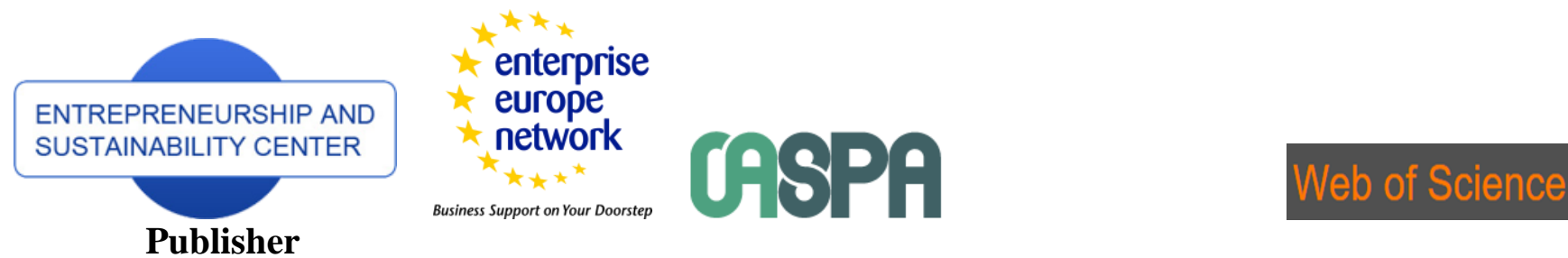

http://jssidoi.org/esc/home

1) Clarivate

Analytics

\title{
SOCIAL MEDIA IN THE CONTEXT OF TECHNOLOGY ACCEPTANCE MODEL*
}

\author{
Igor Fedorko ${ }^{1}$, Richard Fedorko ${ }^{2}$, Beata Gavurova ${ }^{3 *}$, Radovan Bacik ${ }^{4}$ \\ 1,2,4 University of Prešov, Faculty of Management, Konštantínova 16, 08001 Prešov, Slovakia \\ ${ }^{3}$ Technical University of Košice, Faculty of Mining, Ecology, Process Control and Geotechnologies, Letná 9 ,
} 04200 Košice, Slovakia

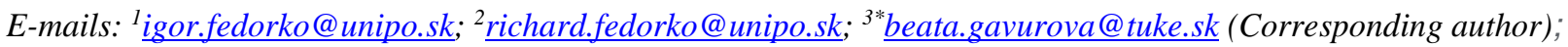
radovan.bacik@unipo.sk

Received 12 February 2021; accepted 25 May 2021; published 30 September 2021

\begin{abstract}
Based on the analysis of previous research in the field of technological acceptance models, the aim of this study is to clarify the significance of individual social media factors in connection with the use of electronic banking in the light of unified theory of acceptance and use of technology. The aim of the article is to describe a model that identifies the influence of social media use factors on the use of electronic banking. The purpose of this model is to explain how these factors influence user behavior in the context of using electronic banking. To obtain primary data sources, we used the exploratory method through a questionnaire survey, which was attended by 948 respondents who are Internet users and users of banking services in an electronic environment. We verified the adequacy of the composition of the research sample with Cronbach alpha. We solved the verification of hypotheses through confirmatory factor analysis and modeling of structural equations. The results, using the WLSMV estimation method, found a negative significant impact (negative linear dependence) of the social media factor on the expected efforts, which are further related to the use of electronic banking.
\end{abstract}

Keywords: Technology acceptance; social media; online banking adoption

Reference to this paper should be made as follows: Fedorko, I., Bacik, R., Gavurova, B., Fedorko, R. 2021. Social media in the context of technology acceptance model. Entrepreneurship and Sustainability Issues, 9(1), 519-528. http://doi.org/10.9770/jesi.2021.9.1(32)

JEL Classifications: M15, M21, M31

Additional disciplines Personnel Management

\footnotetext{
* This article is one of the partial outputs under the scientific research grant VEGA 1/0694/20 - Relational marketing research - the perception of e-commerce aspects and its impact on purchasing behaviour and consumer preferences and VEGA 1/0609/19 - Research on the development of electronic and mobile commerce in the aspect of the impact of modern technologies and mobile communication platforms on consumer behaviour and consumer preferences and 1/0807/19 - Research on the determinants of trading behavior and marketing effects in the area of neuromarketing and the relation to neuro-linguistic programming.
} 


\section{ENTREPRENEURSHIP AND SUSTAINABILITY ISSUES}

ISSN 2345-0282 (online) http://jssidoi.org/jesi/

2021 Volume 9 Number 1 (September)

http://doi.org/10.9770/jesi.2021.9.1(32)

\section{Introduction}

New technologies and the big expansion of social media websites have transformed interaction in the online space, and many online retailers and industries have provided new opportunities to reach their audiences, including the field of Internet banking (Małkowska et al. 2021).

The coverage of social networks worldwide is still growing. The global digital population is 4.66 billion active Internet users in January 2021, of which 4.2 billion are active social media users, which represents about $90 \%$ (Johnson, 2021). For comparison, in 2012, 63.1\% of Internet users also used social networking services. The worldwide increase in the use of smartphones and other mobile devices, such as tablets, opened up the possibilities of social networks with extended functions. Most social networks are also available as mobile applications, while some networks are optimized for Internet browsers. Facebook is currently the market leader in terms of size and reach. This social network has been shaping the social media market since its launch and has faced various discussions on user privacy (American Marketing Association, 2014).

According to a 2008 Forrester study, up to $75 \%$ of Internet users got to interact with social media through social networks, reading blogs, or writing reviews on e-commerce websites. Significant growth in social media usage should not be ascribed only to young users, as also members of the so-called Generation X, now 35 to 44 years old users are avid users of social media. It is therefore important to note that social media is a revolutionary trend that companies operating in the online environment should pay attention to (Bernardelli et al. 2021; Ahmed et al. 2020). Despite these facts, few companies are active in the online world - the world in which consumers can talk about companies but companies have little to no control over what is being said / written about them (Almeida et al., 2019; Kaplan and Haenlein, 2010).

Communication between banks and consumers is therefore now taking place at various levels in the digital space (Korzeb \& Niedziółka, 2020). The main products of banks include internet banking, and with this research we want to examine the area of relations between users of social networks and banks, specifically by examining the degree of acceptance of banking technology through a stimulating factor of social media.

\section{Theoretical background}

The idea of publishing online content belongs to the era of the so-called Web 1.0. Blogs, wikis and social web projects can be found in Web 2.0. Although Web 2.0. is not connected with any specific technical update of the World Wide Web as such, it is a set of basic functionalities that differentiate it from Web 1.0. If Web 2.0. is being characterized by ideological and technological basis, User Generated Content (UGC) can be understood as a summary of all the ways in which people use social media. The term, which gained widespread popularity in 2005, is commonly used to describe the various forms of media content that are publicly available and created by end users (Kaplan and Haenlein, 2010). According to the Organization for Economic Co-operation and Development (OECD, 2007), a UGC must meet three basic requirements in order to be considered as such: it must be published or made available on a publicly accessible website or social network accessible to a selected group of people, it must demonstrate certain creative efforts and need to be developed outside of professional practices and procedures.

Based on their analysis, Kaplan and Heinlein (2010) define social media as a group of Internet applications, which are based on ideological and technological foundations of Web 2.0., and which enable the creation and exchange of user-generated content (User Generated Content). In addition to this general definition, the authors mention the existence of different types of social media, which need to be further distinguished, but there is no systematic way in which different social media can be categorized (e.g. Čepel, 2019). If we want to try to create a system of social 
media classification, it is necessary to rely on a set of theories in the field of media research (social existence, media richness) and social processes (self-presentation).

Social media includes a wide range of online, the so-called word-of-mouth forums, including blogs, companysponsored discussion forums and chat rooms (Worimegbe et al., 2020), C2C email, product and service customer review portals and discussion forums, other online discussion forums, sites featuring digital content for image, film, photo or music content, and social networks, social media are numerous and diverse (Mangold and Faulds, 2009).

Table 1 Example of social media categorization

\begin{tabular}{|l|l|}
\hline Type of social media & Example \\
\hline Social networks & Facebook, MySpace \\
\hline Creative content sharing sites & $\begin{array}{l}\text { Video: Youtube } \\
\text { Photos: Flickr } \\
\text { Music: Jamendo } \\
\text { Intellectual property: Creative Commons }\end{array}$ \\
\hline User-sponsored blogs & cnet.com \\
\hline $\begin{array}{l}\text { Company-sponsored websites } \\
\text { campaigns }\end{array}$ & $\begin{array}{l}\text { Dove's campaign "Real beauty" } \\
\text { click2quit.com }\end{array}$ \\
\hline invitations & ASmallWorld.net \\
\hline Professional social networks & LinkedIn \\
\hline Collaborative websites & Wikipedia \\
\hline Virtual worlds & Second Life \\
\hline Commercial communities & eBay, Amazon, iStockphoto \\
\hline Other & $\begin{array}{l}\text { Podcasts } \\
\text { Educational content sites (iTunes U, MIT } \\
\text { OpenCourseWare) } \\
\text { Open-Source Software communities (Wordpress) }\end{array}$ \\
\hline \multicolumn{2}{|l|}{ Souce: Mangold, Faulds (2009) } \\
\hline
\end{tabular}

In the traditional communication paradigm, elements of the promotional mix are coordinated to develop Integrated Marketing Communication (IMC) while the content, frequency, timing and medium of communication are given by the organization in cooperation with its paid agents (advertising agencies, marketing research firms, PR consultants). The flow of information beyond the paradigm is generally limited to face-to-face and word-ofmouth communication between individual consumers, who have minimal impact on market dynamics due to their limitations (Mayzlin, 2006). Despite the age of social media, the management of the content, timing and frequency of information dissemination is not fully in the hands of managers (Streimikiene \& Ahmed, 2021). In the new paradigm, information about products and services may also come from the market itself (Ferencakova et al., 2020). This information is based on the experience of individual consumers and is distributed through the traditional components of the promotional mix (Gorączkowska, 2020). In the scheme of the new communication paradigm, marketing managers should recognize the power and critical nature of discussions conducted by consumers on social media (Žufan et al., 2020). The impact of consumer interactions on social media on the development and implementation of IMC strategies is illustrated in the following points as summarized by Mangold and Faulds (2009): The Internet has become a mass media tool for communicating with consumers (Rashtchy et al., 2007). Consumers are moving away from traditional sources of advertising such as radio, television, magazines and newspapers. Consumers demand more control over the content they receive and their media consumption. They also require immediate access to information at their own convenience (Khan et al., 


\section{ENTREPRENEURSHIP AND SUSTAINABILITY ISSUES}

ISSN 2345-0282 (online) http://jssidoi.org/jesi/

2021 Volume 9 Number 1 (September)

http://doi.org/10.9770/jesi.2021.9.1(32)

2019; Rashtchy et al., 2007; Vollmer and Precourt, 2008). Consumers more often turn to different types of social media to carry out their purchasing decision (Lempert, 2006; Vollmer and Precourt, 2008). Social media are perceived as a more credible source of information about products and services, as corporate-sponsored communication through traditional elements of the promotional mix (Foux, 2006).

Advance in online technologies and related applications allow consumers to interact in diverse ways with businesses and institutions. More and more organizations are investing heavily in online customer-centric solutions and technologies in an effort to increase their share of the online market (Kwon et al., 2002; Moss et al., 2006). In recent years, the Internet has grown steadily and offers a number of web applications that provide organizations with a new way to reach and retain consumers by offering new services and products (Tan and Teo, 2000). In the interest of both parties (organizations and consumers), it is very important to monitor and analyze real perceptions and the main reasons for consumers' willingness to adapt these technologies to use these applications (Lee, 2009; Liao and Cheung, 2002). Internet banking has proven to be one of the most profitable ecommerce platforms (Lee, 2009). Most research on the adoption and continued use of technology is based on the Technology Acceptance Model (TAM) (Davis, 1989). The Unified Theory of Acceptance and Use of Technology (UTAUT) (Venkatesh et al., 2003) is based on and expands TAM in an effort to integrate the eight most widely used models of technological acceptance research into one practical model. UTAUT therefore includes a framework for current studies of the adoption of Internet banking. In this study, we use the fundamentals of this concept to analyze the relationships between its factors and social media. Expected performance is the degree to which the use of technology helps the consumer to perform certain activities. The expected effort is the simplicity with which consumers use technology.

\section{Metodology and hypothesis development}

The aim of the paper is to determine the significance of the influence of social media on performance expectancy and effort expectancy factors in the context of the UTAUT model and the use of online banking technology. To better understand the use of online banking, we have extended the UTAUT model by including a new construct: social media. We are of the opinion that the adoption and use of social media in the context of online banking can expand the UTAUT model in the field of information systems acceptance. That is why we have drawn up the following hypotheses:

H1. Social media has a positive impact on effort expectancy.

H2. Social media has a positive impact on performance expectancy.

We have solved the research problem and verified the hypotheses by several levels of solution. To obtain primary data sources, we used the exploratory method through a questionnaire survey, which was attended by 454 respondents who are Internet users and users of banking services in an electronic environment. The relatively high level of education and slight male dominance in terms of gender of respondents in the survey sample reflects the profile of online consumers across different countries in the European Union (Al-Qeisi et al., 2014). The questionnaire consisted of closed questions using Lickert's seven-point scale of answers. We verified the adequacy of the composition of the research sample with Cronbach alpha. We solved the verification of hypotheses through confirmatory factor analysis and modeling of structural equations.

In the original construction of the model of technological acceptance, on which our research is based, we incorporated a factor which in the current circumstances of social media boom can significantly influence the use of online banking. This factor is social media (abbreviation SM). Social media can be characterized as media through which banking institutions communicate with their customers, market their products, policies, provide customer support and promote their products and services. For better understanding of respondents, we 
supplemented the individual attributes of the social media factors with additional information in parentheses. The questions we used in the survey were as follows (SM 1-4):

SM 1: Using social media of my bank increases the likelihood of successful completion of banking tasks that are important to me (for example Facebook, Twitter, Google + and the like)

SM 2: Using social media of my bank helps me accomplish my banking tasks faster (for example Facebook, Twitter, Google + and the like);

SM 3: I have found that social media is useful in my communication with the bank (e.g. direct communication, following news, etc. through Facebook, Twitter, Google + and the like);

SM 4: Using social media makes my life easier (e.g. Facebook, Twitter, Google + and the like - in connection with the tasks you perform in your online banking).

In relation to online banking, respondents perceive social media mainly as neutral, as in each of the four questions the answer expressing a neutral attitude prevailed, mostly in the question concerning the help of social media when performing online banking tasks (37\%). The most positive answers were recorded for the question SM 4 - a total of $45.82 \%$ of positive answers. The most negative answers were recorded in question SM 3, which deals with the usefulness of the respondent's communication with the bank via social media.

Table 2 Summary of results for the social media factor

\begin{tabular}{|c|c|c|c|c|c|c|c|}
\hline \multirow{3}{*}{ Factor } & 1 & 2 & 3 & 4 & 5 & 6 & 7 \\
\hline & $(\%)$ & $(\%)$ & $(\%)$ & $(\%)$ & $(\%)$ & $(\%)$ & $(\%)$ \\
\hline & $\mathrm{N}$ & $\mathrm{N}$ & $\mathrm{N}$ & $\mathrm{N}$ & $\mathrm{N}$ & $\mathrm{N}$ & $\mathrm{N}$ \\
\hline \multirow{2}{*}{ SM 1} & 8.81 & 6.17 & 7.27 & 37.00 & 16.30 & 13.44 & 11.01 \\
\hline & 40 & 28 & 33 & 168 & 74 & 61 & 50 \\
\hline \multirow{2}{*}{ SM 2} & 11.23 & 9.91 & 9.25 & 33.26 & 15.20 & 12.33 & 8.81 \\
\hline & 51 & 45 & 42 & 151 & 69 & 56 & 40 \\
\hline \multirow{2}{*}{ SM 3} & 15.86 & 9.91 & 12.78 & 31.50 & 12.56 & 9.03 & 8.37 \\
\hline & 72 & 45 & 58 & 143 & 57 & 41 & 38 \\
\hline \multirow{2}{*}{ SM 4} & 12.56 & 9.03 & 8.59 & 24.01 & 15.64 & 13.44 & 16.74 \\
\hline & 57 & 41 & 39 & 109 & 71 & 61 & 76 \\
\hline
\end{tabular}

\section{Results}

To compare the results of factor analysis, we chose an estimation method for calculating values and coefficients WLSMV, which can be defined as follows - it does not assume normally distributed variables and is presented as the best choice for modeling categorical or sequential data (Brown and Venkatesh, 2005). In our case, we use scaled answers for individual factors as this type of estimation method seems to be a better option here.

In the educational, social, and behavioral sciences, sequential observations of categorical variables are most often operationalized by latent constructs in structural regression models. Testing of ordinal variables as if they were continuous variables, the accuracy and precision of parametric model estimates, standard errors, and goodness-offit tests may be compromised, thus leading to misinterpreted statistical conclusions. Robust estimates such as WLSMV (weighted least squares) method, have been addressed in the literature in recent decades and are considered more applicable than the current Maximum Likelihood (ML) theory when ordinal variables are being analyzed (Cheng-Hsien, 2014). 
Table 3 Overview of SEM results using the WLSMV method

\begin{tabular}{|c|c|c|c|}
\hline $\begin{array}{c}\chi^{2} \\
\text { (chi square) }\end{array}$ & $\begin{array}{c}\text { df } \\
\text { (degrees of freedom) }\end{array}$ & $\begin{array}{c}\text { CFI } \\
\text { (comparative fit index) }\end{array}$ & $\begin{array}{c}\text { RMSEA } \\
\text { (Root Mean Square Error of } \\
\text { Approximation) }\end{array}$ \\
\hline 899.229 & 447 & 0.972 & 0.047 \\
\hline
\end{tabular}

Table 4 SEM for SM factor - Overview of the results of latent variables

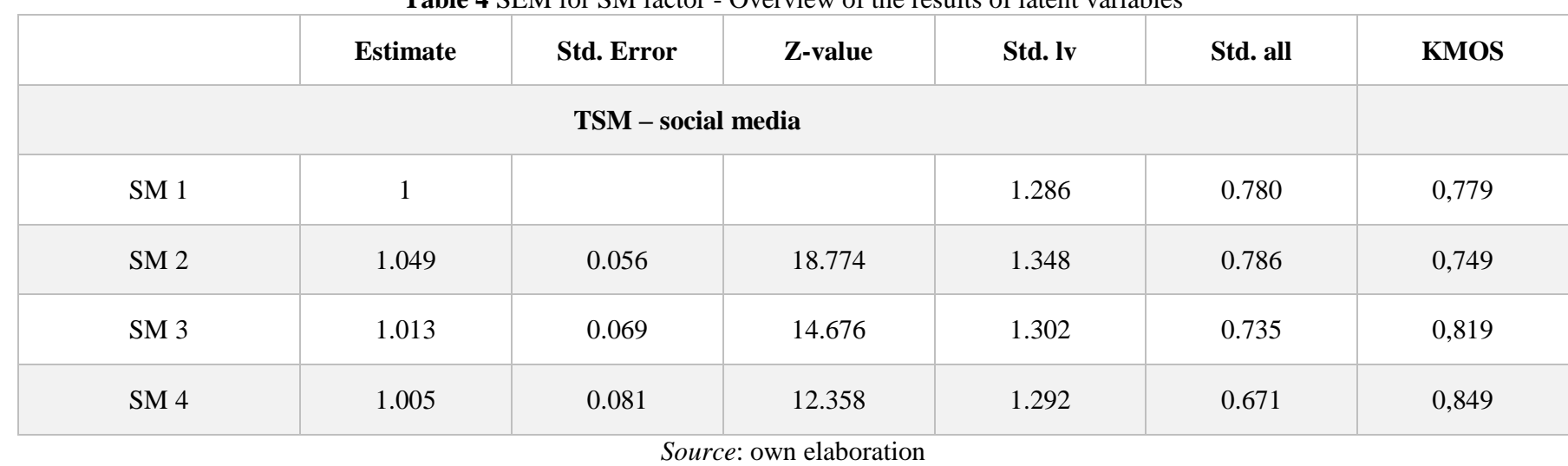

With social media, there is a question concerning the use of social media to perform online tasks, or the usefulness of social media in communication with the bank. The highest values were recorded in the first three questions, i.e. the questions which deal with the performance of banking tasks. The lowest significance, which is not very striking given the circumstances, was recorded in the question exploring whether social media make life easier when it comes to performing banking tasks. When verifying the reliability of the sample, the Cronbach Alpha indicator reached a value of 0.886 .

\section{Structural model and hypothesis testing}

After a detailed analysis of partial results, taking into account both analyzes and methods of calculation of factor analysis, we proceeded to the evaluation of our research hypotheses and focused on the regression relationships between individual variables. Detailed statistical values of the model can be found in the individual tables, which show the coefficients of calculations for both methods used to calculate the factor analysis.

Table 5 SEM when estimating WLSMV - Overview of the results of the structural regression model

\begin{tabular}{|c|c|c|c|c|c|c|}
\hline & Estimate & Std. Error & Z-value & $\mathbf{p}(>|\mathbf{z}|)$ & Std.lv & Std.all \\
\hline TEE & & & & & -1.559 \\
\hline TSM & -1.511 & 0.425 & -3.557 & 0.000 & -1.559 \\
\hline TPE & & & & & -0.492 \\
\hline TSM & -0.432 & 1.060 & -0.408 & 0.684 & -0.492 \\
\hline
\end{tabular}

Source: own elaboration

For the purposes of this study, when evaluating research hypotheses, we did not explicitly define null hypotheses, which represent a well-known relationship to the formulated alternative hypothesis and expresses the differences. In each of the hypotheses, we observe the effect of the independent variable on the dependent variable. As part of the evaluation of hypotheses, the table marks estimation methods, while the coefficients always correspond to the 


\section{ENTREPRENEURSHIP AND SUSTAINABILITY ISSUES}

ISSN 2345-0282 (online) http://jssidoi.org/jesi/

2021 Volume 9 Number 1 (September)

http://doi.org/10.9770/jesi.2021.9.1(32)

stated method. Due to the nature of the research, the structural model is developed uniformly based on the WLSMV estimation method.

Table 6 Overview of statistical evaluation of the research hypotheses

\begin{tabular}{|c|c|c|c|c|c|c|c|}
\hline & Path & Coefficient & S.E. & $\mathbf{t}(\mathbf{Z})$ & $\mathbf{p}$ & Result & Estimator \\
\hline H1 & TSM>TEE & -1.511 & 0.425 & -3.557 & $* * *$ & Accept & WLSMV \\
\hline H2 & TSM $>$ TPE & -0.042 & 0.035 & -1.193 & & Reject & WLSMV \\
\hline
\end{tabular}

Source: own elaboration

H1. Social media has a significant impact on the effort expectancy.

In the context of the hypothesis, we focused on the social media factor and its impact on the effort expectancy. The research results show a negative, statistically significant result. We obtained the values using the WLSMV estimation methods.

H2. Social media has a positive impact on performance expectancy.

Another hypothesis deals with the social media and their impact on the performance expectancy in connection with carrying tasks in online banking. The results point to negative and statistically insignificant coefficients. Thus, we refute the hypothesis. We obtained the values using the WLSMV estimation methods.

\section{Conclusion and discussion}

In this case, based on the evaluation of research hypotheses, using the WLSMV estimation method, we found a negative significant impact (negative linear dependence) of the social media factor on the effort expectancy. This relationship can be interpreted as a situation where individual users use social media to communicate with their bank (perform banking tasks) and subsequently has to exert more performance effort to fulfill the task. By adding the social media factor to the model we arrived at interesting findings, namely the existence of its indirect significant impact on the efforts expectancy and the possibility of further research in this area.

Banking institutions, as well as other companies and individuals, gain many benefits from well-designed websites, effective communication on social networks, and also by exploiting the potential of mobile marketing. Our research has the ambition to meaningfully transform the results into practice and, in the form of recommendations, apply findings concerning the behavioral intent for the use of information systems. The process of deeper implementation of social media into the marketing communication of banks may ultimately result in a simpler adoption of new technology, the adoption of procedures and a higher acceptance of the use of technology. With a unified theory of acceptance and use of technology as a theoretical foundation, this work adapts new constructs and definitions from the model in the context of the adaptation of online banking technology.

Future research into the use of Internet banking technology, also based on our results, can be directed to the field of social media, as this factor, in understanding the UTAUT model, has proven to be an attribute of potential importance and we assume that its significance will be in the coming years. user perspective, user experience and ease of use of technology are increasing. 


\section{ENTREPRENEURSHIP AND SUSTAINABILITY ISSUES}

ISSN 2345-0282 (online) http://jssidoi.org/jesi/ 2021 Volume 9 Number 1 (September)

http://doi.org/10.9770/jesi.2021.9.1(32)

\section{References}

Ahmed, R. R., Romeika, G., Kauliene, R., Streimikis, J., \& Dapkus, R. (2020). ES-QUAL model and customer satisfaction in online banking: evidence from multivariate analysis techniques. Oeconomia Copernicana, 11(1), 59-93. https://doi.org/10.24136/oc.2020.003

Almeida, F., Almeida, J., \& Mota, M. (2019). Perceptions and trends of booking online payments in Tourism. Journal of tourism and services, 10(18), 1-15. https://doi.org/10.29036/jots.v10i18.39.

Al-Qeisi, K., Dennis, C., Alamanos, E., \& Jayawardhena, C. (2014). Website design quality and usage behavior: Unified Theory of Acceptance and Use of Technology. Journal of Business Research, 67(11), 2282-2290.

American Marketing Association (2014). Number of social network users worldwide from 2010 to 2018 (in billions), available at: http://www.statista.com/statistics/278414/number-of-worldwide-social-network-users

Bernardelli, M., Korzeb, Z., \& Niedziółka, P. (2021). The banking sector as the absorber of the COVID-19 crisis? Economic consequences: perception of WSE investors. Oeconomia Copernicana, 12(2), 335-374. https://doi.org/10.24136/oc.2021.012

Brown, S. A., \& Venkatesh, V. (2005). A model of adoption of technology in the household: A baseline model test and extension incorporating household life cycle. Management Information Systems Quarterly, 29(3), 11.

Čepel, M. (2019). Social and cultural factors and their impact on the quality of business environment in the SME segment. International journal of entrepreneurial knowledge, 7(1), 65-73. https://doi.org/10.37335/ijek.v7i1.88

Ferencakova, L., Gajdka, K., Netek, V. \& Kapoun, P. (2020). Engaging customers on facebook coffee shops' brand-fan pages. International Journal of Entrepreneurial Knowledge, 8(1), 65-75. https://doi.org/10.37335/ijek.v8i1.110

Davis, F. D. (1989). Perceived usefulness, perceived ease of use, and user acceptance of information technology. Management Information Systems Quarterly, 319-340.

Foux, G. (2006). Consumer-generated media: Get your customers involved. Brand strategy, 8(202), 38-39.

Gorączkowska, J. (2020). Enterprise innovation in technology incubators and university business incubators in the context of Polish industry. Oeconomia Copernicana, 11(4), 799-817. https://doi.org/10.24136/oc.2020.032

Johnson, J. (2021). Global digital population as of January 2021 (in billions), available at: https://www.statista.com/statistics/617136/digital-population-worldwide/

Kaplan, A. M., \& Haenlein, M. (2010). Users of the world, unite! The challenges and opportunities of Social Media. Business horizons, 53(1), 59-68.

Khan, K.A., Çera, G., \& Nétek, V. (2019). Perception of the selected business environment aspects by service Firms. Journal of Tourism And Services, 10(19), 111-127. https://doi.org/10.29036/jots.v10i19.115

Korzeb, Z., \& Niedziółka, P. (2020). Resistance of commercial banks to the crisis caused by the COVID-19 pandemic: the case of Poland. Equilibrium. Quarterly Journal of Economics and Economic Policy, 15(2), 205-234. https://doi.org/10.24136/eq.2020.010

Kwon, O. B., Kim, C. R., \& Lee, E. J. (2002). Impact of website information design factors on consumer ratings of web-based auction sites. Behaviour \& Information Technology, 21(6), 387-402.

Lee, M. C. (2009). Factors influencing the adoption of internet banking: An integration of TAM and TPB with perceived risk and perceived benefit. Electronic commerce research and applications, 8(3), 130-141.

Lee, K. C., Chung, N. (2011). Exploring antecedents of behavior intention to use Internet banking in Korea: adoption perspective. Eadoption and socio-economic impacts: Emerging infrastructural effects, 38-55, IGI Global.

Lempert, P. (2006). Caught in the Web. Progressive Grocer, 85(12), 15-28.

Li, C. H. (2014). The performance of MLR, USLMV, and WLSMV estimation in structural regression models with ordinal variables, Michigan State University. 


\section{ENTREPRENEURSHIP AND SUSTAINABILITY ISSUES}

ISSN 2345-0282 (online) http://jssidoi.org/jesi/ 2021 Volume 9 Number 1 (September) http://doi.org/10.9770/jesi.2021.9.1(32)

Liao, Z., \& Cheung, M. T. (2002): Internet-based e-banking and consumer attitudes: an empirical study. Information \& Management, 39(4), 283-295.

Małkowska, A., Urbaniec, M., \& Kosała, M. (2021). The impact of digital transformation on European countries: insights from a comparative analysis. Equilibrium. Quarterly Journal of Economics and Economic Policy, 16(2), 325-355. https://doi.org/10.24136/eq.2021.012

Mangold, W. G., \& Faulds, D. J. (2009). Social media: The new hybrid element of the promotion mix. Business Horizons, 52(4), 357-365.

Mayzlin, D. (2006). Promotional chat on the Internet. Marketing science, 25(2), 155-163.

Moss, G., Gunn, R., \& Heller, J. (2006). Some men like it black, some women like it pink: consumer implications of differences in male and female website design. Journal of Consumer Behaviour, 5(4), 328-341.

OECD (1998). Dismantling the Barriers to Global Electronic Commerce, Turku (Finland): 19-21 November 1997 - Conference Report, OECD Digital Economy Papers, No. 38, OECD Publishing, Paris, available at: http://dx.doi.org/10.1787/236647320075

Rashtchy, F., Kessler, A. M., Bieber, P. J., Shindler, N. H., \& Tzeng, J. C. (2007). The user revolution: The new advertising ecosystem and the rise of the Internet as a mass medium, Minneapolis, MN: Piper Jaffray Investment Research.

Streimikiene, D., \& Ahmed, R. R. (2021). The integration of corporate social responsibility and marketing concepts as a business strategy: evidence from SEM-based multivariate and Toda-Yamamoto causality models. Oeconomia Copernicana, 12(1), 125-157. https://doi.org/10.24136/oc.2021.006

Tan, M., \& Teo, T. S. (2000). Factors influencing the adoption of Internet banking. Journal of the Association for information Systems, $1(1), 5$.

Venkatesh, V., Morris, M. G., Davis, G. B., \& Davis, F. D. (2003). User acceptance of information technology: Toward a unified view. Management Information Systems Quarterly, 425-478.

Vollmer, C., \& Precourt, G. (2008). Always on: Advertising, marketing, and media in an era of consumer control. McGraw Hill Professional.

Worimegbe, P. M., Worimegbe, T. M., \& Abiola-Oke, E. (2020). Gamification and customers experience in the hospitality industry. Journal of Tourism and Services, 21(11), 71-87. https://doi.org/10.29036/jots.v11i21.165

Žufan, J., Civelek, M., Hamarneh, I., \& Kmeco, L. (2020). The impacts of firm characteristics on social media usage of SMEs: Evidence from the Czech Republic. International journal of entrepreneurial knowledge, 8(1), 102-113. http://dx.doi.org/10.37335/ijek.v8i1.111

\section{Acknowledgements}

This article is one of the partial outputs under the scientific research grant VEGA 1/0694/20 - Relational marketing research - the perception of e-commerce aspects and its impact on purchasing behaviour and consumer preferences and VEGA 1/0609/19 - Research on the development of electronic and mobile commerce in the aspect of the impact of modern technologies and mobile communication platforms on consumer behaviour and consumer preferences and 1/0807/19 - Research on the determinants of trading behavior and marketing effects in the area of neuromarketing and the relation to neuro-linguistic programming 


\section{ENTREPRENEURSHIP AND SUSTAINABILITY ISSUES}

ISSN 2345-0282 (online) http://jssidoi.org/jesi/ 2021 Volume 9 Number 1 (September) http://doi.org/10.9770/jesi.2021.9.1(32)

Igor FEDORKO focuses his research on the issue of models of unified theory of acceptance and use of technology. He also focuses his publication outputs on the mentioned issues. As a co-investigator, he has collaborated and is collaborating on several successful scientific research projects and grants. ORCID ID: https://orcid.org/0000-0003-1974-7465

Richard FEDORKO has been working as a lecturer at the Department of Marketing and International Trade of the University of Prešov since 2014. In his research activities he is focusing on the issues of online marketing and e-commerce, especially on the fields of online advertising, online reputation, social media, customer support, consumer behaviour and mobile marketing.

ORCID ID: https://orcid.org/0000-0003-3520-1921

Beata GAVUROVA (corresponding author) is an expert in finance, financial analysis and financial risk management. She focuses in her research work on issues of measurement and performance management in various sectors, process management and process optimization, strategic and performance benchmarking. Her dominant research area is the development and testing in the management and performance measurement, the evaluation of methodologies and the preparation of an application platform for innovative management and performance measurement with the support of ICT. She led several national projects, has participated in many international projects targeting the innovative applications of ICT in the private and public sector.

ORCID ID: https://orcid.org/0000-0002-0606-879X

Radovan BACIK has been working as a lecturer at the Department of Marketing and International Trade of the University of Prešov since 2009. In his research activities he is focusing on the issues of Public relations, Public relations in tourism, marketing of selected areas, strategic marketing, presentation of management and marketing, communication in management, branding and innovation and online marketing.

ORCID ID: https://orcid.org/0000-0002-5780-3838

Make your research more visible, join the Twitter account of ENTREPRENEURSHIP AND SUSTAINABILITY ISSUES: @Entrepr69728810

Copyright (C) 2021 by author(s) and VsI Entrepreneurship and Sustainability Center

This work is licensed under the Creative Commons Attribution International License (CC BY).

http://creativecommons.org/licenses/by/4.0/

c) (i) Open Access 